Supporting Information

\title{
Enhancing Collagen Mineralization with Amelogenin Peptide: Towards the Restoration of Dentin
}

Kaushik Mukherjee, Gayathri Visakan, Jin-Ho Phark, and Janet Moradian-Oldak *

Number of pages: 2

Figures: 2

Figure S1: Peptide- apatite binding

Figure S2: Tensile strength testing sample preparation schematic 


\section{P26 demonstrates a binding affinity to HAP}

Adsorption behavior of phosphorylated P26 onto synthetic apatite was compared to a phosphorylated leucine-rich amelogenin peptide (LRAP), used as a control in this experiment. LRAP is the smallest alternatively spliced product of the amelogenin gene known to have an essential role in proper enamel mineral formation. ${ }^{1,2}$ Two different concentrations of synthetic and native amelogenin peptides (P26 and LRAP, respectively) were dissolved in deionized water, fully stirred with HAP powder and then centrifuged. The amount of the peptide adsorbed on HA was calculated by the decrease of peptide in the solution.

Figure $\mathrm{S} 1$ demonstrates $Q$ values which are defined as the amount of peptide adsorbed $\left(\mu \mathrm{mol} / \mathrm{m}^{2}\right)$ of hydroxyapatite, indicative of P26 and LRAP binding to HAP at different concentrations. At 0.2 and $0.8 \mathrm{mg} / \mathrm{ml}$, the $Q$ values $\left(\mu \mathrm{mol} / \mathrm{m}^{2}\right)$ of P26 were $0.041 \pm 0.028$ and $0.249 \pm 0.0781$ respectively, and for LRAP $0.076 \pm 0.005$ and $0.209 \pm 0.0297$. Statistical analysis indicated no significant difference $(p>0.05)$ in HAP binding between P26 and LRAP at either concentration.

\section{Experimental section}

Apatite binding experiments. The adsorption experiments were conducted in $10 \mathrm{mM}$ HEPES at $\mathrm{pH}$ 7.4. Hydroxyapatite crystals (HAP) were obtained from the National Institute of Standards and Technology. Peptides P26 and LRAP (leucine-rich amelogenin peptide) were prepared in HEPES at two different concentrations $(0.2$ and $0.8 \mathrm{mg} / \mathrm{mL}$ to a final volume of $500 \mu \mathrm{L})$. To evaluate the binding capacity of the peptides on HAP, HAP $(10 \mathrm{mg})$ was added to the peptide solutions and vortexed on a slow shaker at $37{ }^{\circ} \mathrm{C}$ overnight. Each sample was prepared in quadruplicate and the experiments were repeated twice $(n=2)$. The tubes were 
then centrifuged at $12,500 \mathrm{rpm}$ for $10 \mathrm{mins}$. The aliquots $(25 \mu \mathrm{L})$ were separated and analyzed for protein using a BCA (bicinchoninic acid) protein assay kit (Pierce). Standard calibration curves were constructed using solutions of LRAP and peptide binding was evaluated using visible absorbance analysis (Beckman DU 640 UV/Vis Spectrophotometer) at a wavelength of $562 \mathrm{~nm}$. The amount of peptide $(\mu \mathrm{mol})$ adsorbed per $\mathrm{m}^{2}$ of HAP (Q) was calculated as described previously (See ref. 56 in main manuscript).

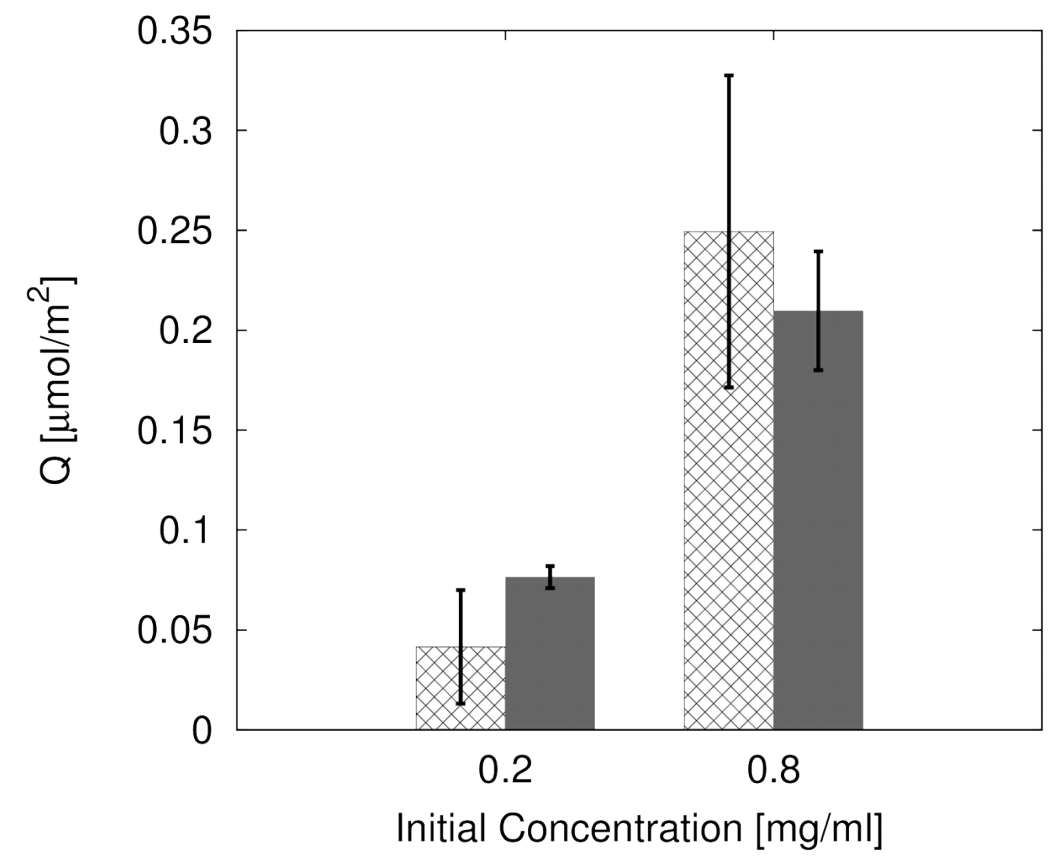

Figure S1. Peptide- Apatite binding. Comparative binding of phosphorylated peptides P26 and LRAP onto synthetic hydroxyapatite $(n=3)$. $Q$ is the amount of protein adsorbed $\left(\mu \mathrm{mol} / \mathrm{m}^{2}\right)$ on hydroxyapatite. P26: Synthetic peptide (dashed); LRAP: Leucine-rich amelogenin peptide (grey). 

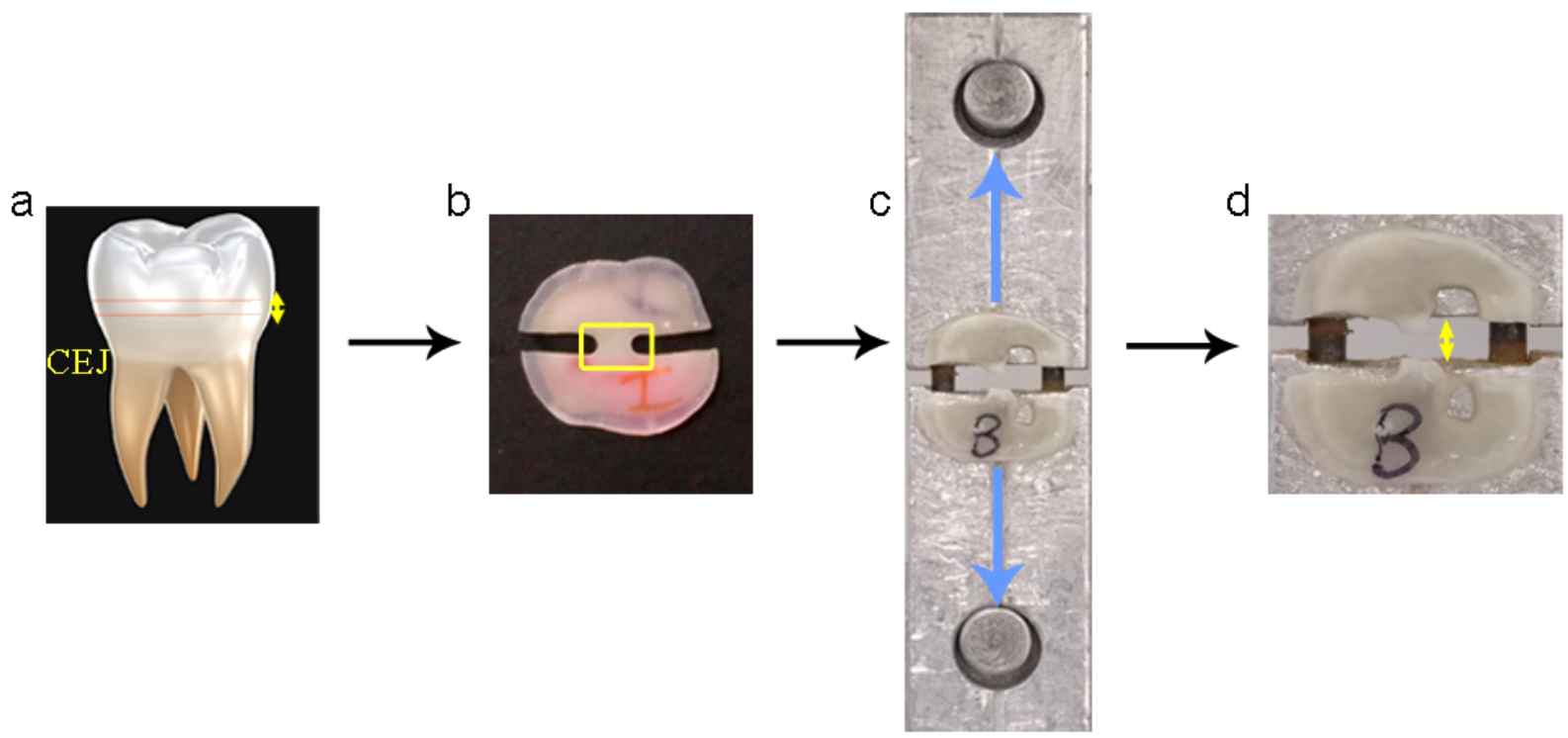

Figure S2. Schematic of (a) sound human molar demonstrating the location of transverse dentin sections above the CEJ. (b) Hour-glass shaped test specimens were prepared and only the bridge (yellow arrowhead) was exposed to a 3-day demineralization followed by a 10- day remineralization cycle. (c, d) To determine the tensile strength, the hydrated sample was mounted on the sample holder between the two hydraulic pull arms of the device and then tested under tension using a Universal Testing Machine (Instron 5965) until fracture.

Ref:

[1] M. L. Paine, W. Luo, D. H. Zhu, P. Bringas Jr, M. L. Snead, J Bone Min Res 2003, 18, 466.

[2] K. Tompkins, A. Veis, Connect Tissue Res 2002, 43, 224. 